\title{
A DEMOCRACIA E SEU NÃO LUGAR
}

\author{
Márcio Bilharinho Naves ${ }^{1}$
}

Um longo processo no qual convergiram tanto as correntes liberais e neoliberais, como de "esquerda", levou-nos a um espécie de consenso universal sobre a democracia como um valor e uma prática inerentes à vida social e política, e, assim, o horizonte absoluto da humanidade. A democracia passa a ser solenemente cultuada como o chão natural do homem racional e livre, a ponto de se interditar a sua crítica, nessa fórmula paradoxal: "ninguém pode ser contra a democracia"!

É assim que a nossa Constituição - resultado de manobras políticas das classes dominantes que resultaram no término do período da ditadura militar - é anunciada como o meio pelo qual se institui o "Estado Democrático", que tem como fundamento, entre outros, a cidadania, a dignidade humana, os "valores" do trabalho e da iniciativa privada, e como objetivos, entre outros, edificar uma sociedade "livre, justa e solidária". Deixemos de lado as evidentes contradições entre defender ao mesmo tempo o capital ("valor" da iniciativa privada) e o trabalho, e defender uma sociedade fundada na liberdade e na "justiça" e ao mesmo tempo na desigualdade estrutural e na dominação de classe próprias do capitalismo, e que o apelo à "fraternidade", à "harmonia social" e à "solução pacífica das controvérsias" tenta conciliar e, desse modo, dissimular. O que mais interessa, é que essa democracia passa a ser protegida contra eventuais ameaças

${ }^{1}$ Professor do Departamento de Sociologia do Instituto de Filosofia e Ciências Humanas da Universidade Estadual de Campinas. 
| 62 |

A democracia e seu não lugar

a ela, como quando é criminalizado todo atentado contra o "Estado Democrático": torna-se "crime inafiançável e imprescritível a ação de grupos armados, civis ou militares, contra a ordem constitucional e o Estado democrático", tipificação que alcança igualmente o que é denominado, de modo vago e impreciso, de "terrorismo". Assim também, só é admissível a existência de partidos políticos desde que o "regime democrático" seja "resguardado". O Ministério Público fica encarregado de defender esse "regime democrático", e se prevê para a defesa do "Estado e das instituições democráticas" a adoção do estado de defesa e do estado de sítio, isto é, de medidas que restringem a democracia (!), tais como as que atingem, no caso do estado de defesa, os direitos de "reunião, ainda que exercida no seio das associações, sigilo de correspondência, sigilo de comunicação telegráfica e telefônica", além da possibilidade de se efetuar prisões "por crime contra o Estado", e, no caso de estado de sítio, a "obrigação de permanência em localidade determinada, detenção em edifício não destinado a acusados ou condenados por crimes comuns, restrições relativas à inviolabilidade da correspondência, ao sigilo das comunicações, à prestação de informações e à liberdade de imprensa, radiodifusão e televisão, na forma da lei, suspensão da liberdade de reunião, busca e apreensão em domicílio", dentre outras. ${ }^{2}$

Nada disso é novo, como se sabe, e faz parte da tradição das democracias burguesas, cujos juristas cuidaram de forjar os tipos penais necessários ao enfrentamento político com as massas trabalhadoras. Aos poucos, no entanto, a própria distinção entre crimes comuns e crimes contra a "ordem social e política" vai sendo dissolvida. Aqui se observa um processo de criminalização que opera um deslocamento decisivo que vai atingir particularmente as formas mais avançadas de luta dos trabalhadores contra a sociedade do capital (e contra, consequentemente, a sua Constituição). Trata-se de negar o caráter político das lutas que ultrapassam os limites da legalidade, portanto,

${ }^{2}$ Cf. Constituição da República Federativa do Brasil, São Paulo, IMESP, 1990.

Um balanço crítico da redemocratização no Brasil 
que ultrapassam a própria democracia. Desse modo, o recurso a todo um conjunto de ações de subversão da ordem burguesa tornam-se crimes comuns, e especialmente, crimes da mais extrema gravidade, denominados de "hediondos", e apenados de modo drástico. O recente julgamento do "caso Battisti" é, nesse sentido, exemplar. A maioria dos ministros do Supremo Tribunal Federal considerou as ações imputadas ao militante italiano, não obstante o fato dele ter pertencido a um organização comunista, cuja atividade evidentemente visava objetivos exclusivamente políticos, como sendo desprovidas desse caráter, simplesmente porque ele recorreu a meios ilegais para alcançar esse desiderato, em um país no qual estaria em vigor a plena democracia. Haveria, assim, uma contradição insanável entre a ação política não prevista legalmente e o "regime democrático", o que levaria a essa desqualificação da própria natureza do ato praticado, de "político" para "comum". Só seria possível, assim, a existência dessa figura do "delito político" quando fossem os atos assim tipificados cometidos em sociedades não democráticas, em ditaduras que não observassem aquele conjunto de princípios garantidores das liberdades públicas e dos direitos individuais. A criminalização da luta social e política torna-se desse modo um meio de assegurar o domínio de classe total da burguesia, já que o campo da democracia é impermeável a qualquer expressão dos interesses das massas, e reproduz integralmente as condições de sua subalternidade ao capital. Mas é também a afirmação de que não pode haver exercício da política fora do espaço democrático, ${ }^{3}$ que política e democracia são a mesma coisa, e que tudo o que ultrapassa a legalidade democrática burguesa decai ao nível degradante do banditismo.

Ao mesmo tempo, correntes expressivas da "esquerda" passaram a redescobrir e revalorizar a democracia, tanto teoricamente, como no exercício da atividade política. Exemplar, nesse sentido, é a melancólica trajetória do Partido Comunista

${ }^{3} \mathrm{Cf}$. a esse respeito o notável trabalho de Bernard Edelman, La légalisation de la classe ouvrière t. 1: L'entreprise, Paris, Christian Bourgeois, 1978. 
| 64 |

A democracia e seu não lugar

Italiano (PCI), que, ao colocar a democracia como horizonte inultrapassável abdicou de qualquer transformação real do sociedade capitalista e passou a ser mais um aparelho de sustentação da ordem burguesa, a tal ponto que os seus quadros não só se opuseram à luta revolucionária levada a cabo pelas organizações operárias armadas - como as "Brigadas Vermelhas"-, como também colaboraram com a repressão a elas, para, por fim, mais recentemente, e depois de abandonar a própria identidade "comunista", se fundir com um partido notabilizado pelos vínculos com a máfia, pela corrupção endêmica e pelo direitismo aberto.

Entre nós, e acompanhando justamente a reelaboração teórica dos italianos, Carlos Nelson Coutinho se consagraria ao difundir a tese originariamente formulada pelo então secretáriogeral do PCI, Enrico Berlinguer, da democracia como "valor universal" ${ }^{\prime 4}$ Mais tarde, a conversão à democracia vai se tornar avassaladora nas organizações de "esquerda", que se transformaram em pouco tempo em defensores dos interesses da burguesia. ${ }^{5} \mathrm{O}$ que está em jogo, aqui, é, antes de mais nada,

\footnotetext{
${ }^{4}$ Carlos Nelson Coutinho, "A democracia como valor universal", in Revista Encontros com a Civilização Brasileira, n 9, 1979. Este artigo suscitou diversas intervenções, como, entre outras, as de Adelmo Genro, "A democracia como valor operário e popular", in Revista Encontros com a Civilização Brasileira, n 17, 1979, José Chasin, "As máquinas param, germina a democracia", in Escrita-Ensaio, n 7, 1980, Márcio Bilharinho Naves, "Contribuição ao debate sobre a democracia", in Temas de Ciências Humanas, $\mathrm{n}^{\circ}$ 10, 1981, Caio Navarro de Toledo, "A modernidade democrática: adeus à revolução?", in Crítica Marxista, n 1, 1994, João Quartim de Moraes, "A universalidade de democracia: esperanças e ilusões", in Ensaios - Ad Hominem, $\mathrm{n}^{\circ} 1$ 1, 1999. Para um balanço amplo desse debate, pode-se ver o excelente trabalho de Flávia Cavalcante Nicolis, Socialismo e democracia: dilemas e perspectivas do debate, Tese de doutorado, Universidade Federal do Rio de Janeiro, 2006. Cf. também Augusto Buonicore, “Qual o valor da democracia?", in http://www.fundaj.gov.br/geral/observanordeste/ buonicore\%20rev.pdf.

${ }^{5}$ O caso mais óbvio é o do Partido dos Trabalhadores que, em seus documentos iniciais, trazia uma retórica anticapitalista tal que o levou a ser considerado
} 
o abandono do marxismo, substituído pela ideologia jurídica (o "humanismo", em suas variadas versões) e pelo economicismo (primado das forças produtivas e da circulação mercantil). E, consequentemente, a impossibilidade de apreender os mecanismos de dominação de classe que tem no direito o seu terreno por excelência. Marx e Engels combateram incessantemente as ameaças que provinham do "socialismo jurídico", fosse ele representado pelos socialistas ricardianos ou pelos socialistas "verdadeiros", por Proudhon, ou por Menger, e até pelos próprios trabalhadores de uma "Liga dos Justos" que acreditava serem os direitos do homem o objetivo final da luta de massas. Nesse sentido, a carta que Proudhon endereça a Marx é reveladora. Nela, o pensador francês identifica o socialismo justamente com um programa jurídico de extensão e efetivação das categorias do direito - a liberdade e a igualdade:

Talvez o senhor ainda conserve a opinião de que nenhuma reforma é hoje possível sem um coup de main, sem o que outrora se chamava uma revolução, e que é apenas uma agitação. Essa opinião, que compreendo, que escuso, que discutirei com prazer, porque compartilhei dela por longo tempo, confesso-lhe que meus últimos estudos revisaram-na completamente. Creio que não precisamos disso para triunfar e que, por consequência, não devemos colocar a ação revolucionária como meio de reforma social, porque esse pretenso meio seria, muito

por parcelas expressivas da militância de esquerda como um instrumento efetivo para uma real transformação social no Brasil, não obstante todas as evidências em contrário, e a presença hegemônica de Lula e seu grupo na organização, revelando os seus estreitos limites. Mas, se do PT pouco se poderia esperar desde o seu nascedouro, o que dizer então de uma suposta "esquerda revolucionária" que praticamente se dissolveu nele e passou a colaborar com a politica burguesa quando o Partido alcançou o poder? Não seria naturalmente por acaso que já nos documentos de fundação do "petismo" e naqueles dos anos iniciais de sua existência, encontremos a defesa abstrata da democracia, em que tantos "marxistas" se reconhecem? 
| 66 |

A democracia e seu não lugar

\begin{abstract}
simplesmente, um apelo à força, ao arbítrio - logo, uma contradição. Coloco-me assim o problema: reintroduzir na sociedade, por uma combinação econômica, as riquezas que dela foram extraídas por uma outra combinação econômica. Noutros termos: na economia política, voltar à teoria da Propriedade contra a Propriedade, de forma a criar aquilo que os socialistas alemães - vocês - chamam de comunidade, e que eu pessoalmente me limitarei, por ora, de chamar de liberdade, igualdade. Creio possuir os meios para resolver este problema dentro de muito pouco tempo: prefiro, pois, queimar a Propriedade em fogo lento, ao invés de lhe dar nova força, fazendo com os proprietários uma São Bartolomeu". ${ }^{6}$
\end{abstract}

Observemos que em Proudhon não se trata apenas de pensar a sociedade pós-capitalista sob o modelo do direito burguês, mas também de limitar a ação política das massas à legalidade, renunciando explicitamente à luta direta, à "ação revolucionária", o que, de resto, é coerente com as suas posições reformistas.

Esse apelo à liberdade e à igualdade, portanto à democracia, como fundamento de uma sociedade comunista, e a renúncia às formas de luta ilegais, é constantemente reposto, atravessando todo o movimento operário e suas organizações. É o caso, por exemplo, de um expressivo intelectual e dirigente do PCI que retoma as teses proudhonianas visando anular a luta da massa trabalhadora. Em um artigo intitulado "Liberalismo e socialismo", Umberto Cerroni sustenta que "qualquer mudança sócio-política", "pode e deve ocorrer apenas nas formas política previstas na Constituição vigente", portanto, qualquer iniciativa de superação do capitalismo deve ser submetida ao "consenso dos cidadãos nas formas previstas na Constituição"

${ }^{6}$ Carta de Proudhon a Marx, in Karl Marx, Miséria da filosofia, São Paulo, Global, 1989, p. 202.

${ }^{7}$ Umberto Cerroni, “Liberalismo e socialismo”, in Novos Rumos, n 18-19,

Um balanço crítico da redemocratização no Brasil 
Assim, tanto a elevação da democracia a "valor universal", como o respeito estrito à legalidade burguesa, removem qualquer traço de distinção entre liberais e comunistas, e, consequentemente, qualquer projeto anticapitalista deixa de fazer sentido.

Uma crítica consequente dessas posições exige a compreensão da natureza da democracia e de sua completa incompatibilidade com qualquer projeto de emancipação dos trabalhadores.

Em uma síntese extrema, podemos dizer que a democracia, fundamentalmente, é o reconhecimento da igualdade universal dos indivíduos, o que já pressupõe a liberdade, pois somente pessoas livres podem se relacionar e tomar decisões em condições igualitárias, sem que haja subordinação de uns sobre outros. Isso significa, portanto, o reconhecimento da expressão de vontade que emana de cada pessoa e que aparece como o fundamento imediato dos vínculos obrigacionais que dela decorrem. De fato, é por meio da manifestação de vontade que um contrato é firmado fazendo nascer a obrigação jurídica, e é justamente por isso que ele é definido como "acordo de vontades". ${ }^{8}$

Ora, se a democracia é uma forma política fundada na liberdade e na igualdade, é preciso constatar que ela somente pode surgir na modernidade, com a emergência da sociedade burguesa. As categorias da liberdade e da igualdade inexistem nas sociedades pré-capitalistas, não sendo possível a sua existência em condições sociais de subordinação pessoal, de sujeição a outrem, de estatutos completamente diferentes entre os indivíduos. Qual a origem dessas categorias? Seguramente, elas não caíram do céu. Como Marx demonstra em O capital, a emergência do homem livre (e igual) decorre da necessidade de se transformar a capacidade de trabalho do homem em

1990, p. 27. Um comentário crítico de Cerroni pode ser visto em: Camilo Onoda Caldas, Perspectivas para o direito e a cidadania - o pensamento jurídico de Umberto Cerroni, São Paulo, Alfa Ômega, 2006.

${ }^{8} \mathrm{E}$ é por isso também que tanto o jurista como o legislador são tão sensíveis a qualquer perturbação que venha a impedir a plena 
| 68 |

A democracia e seu não lugar

mercadoria. O homem é livre, como ele nos mostra, em um duplo sentido: ele é livre no sentido de que está despossuído dos meios de trabalho, e também no sentido de que ele tem capacidade jurídica, de que ele está apto a praticar atos jurídicos, de firmar contratos. ${ }^{9}$ A relação entre o proprietário das condições objetivas da produção e o possuidor da força de trabalho passa necessariamente pela mediação das figuras do direito, a propriedade, a liberdade e a igualdade..$^{10}$ São essas categorias que permitem que o homem se transmute em sujeito de direito, ao mesmo tempo em que o ato da venda da sua força de trabalho, o ato mesmo de sua sujeição, pode aparecer como o seu contrário, como a expressão livre de sua vontade soberana e o momento em que a liberdade e a igualdade se realizam plenamente. ${ }^{11}$

O segredo oculto da democracia, do mesmo modo, encontra-se nessa relação entre as formas do direito e o processo do valor de troca. É somente na sociedade burguesa, na qual ocorre a generalização da forma mercadoria, com a própria força de trabalho se tornando uma mercadoria, que é possível o surgimento de uma forma de Estado que possa aparecer como distinta dos interesses privados que cortam o tecido social. De fato, se o Estado não é a expressão imediata de vontades particulares, então, ele pode aparecer como uma instância impermeável a essas vontades, como a instância pública em contraposição àquele composta pelas necessidades privadas. Ora, em uma sociedade de proprietários de mercadorias, se o Estado beneficiasse um dos contratantes, estaria quebrando a relação

manifestação da vontade, para o que cuidaram de criar no direito civil a doutrina dos "defeitos do ato jurídico", justamente para garantir a vontade livre do sujeito.

${ }^{9}$ Karl Marx, O capital, São Paulo, Abril Cultural, 1983, p. 139-140.

${ }^{10}$ Cf. Karl Marx, cit.

${ }^{11} \mathrm{Cf}$. a esse respeito Bernard Edelman, O direito captado pela fotografia (elementos para uma teoria marxista do direito), Coimbra, Centelha, 1976. Cf. igualmente o importante trabalho de Celso Kashiura Júnior, Crítica da igualdade jurídica - contribuição ao pensamento jurídico marxista, São Paulo, Quartier Latin, 2009.

Um balanço crítico da redemocratização no Brasil 
de reciprocidade inerente à condição de sujeitos de direito de que todos os proprietários estão investidos. O Estado será a garantia dessa igualdade universal que permite que a circulação mercantil seja observada, e assim, ele se configura como estando acima das partes, como garantidor das relações jurídicas. É o que diz Pachukanis: "Aparecendo a título de fiador dessas relações [privadas], o poder se torna um poder social, um poder público, que persegue o interesse imparcial da ordem". ${ }^{12}$

Ao investir o homem na condição de cidadão, tendo a igualdade como o seu princípio fundamental, o Estado revela a sua base real ${ }^{13}$ : o processo do valor de troca, necessário para que se verifique a "comercialização do homem"14: "... à medida que os cidadãos 'participam' do Estado, constitui-se um processo de circulação das vontades políticas análogo ao processo de circulação das mercadorias, posto que a forma de representação fundada na equivalência entre os sujeitos-cidadãos remete ao processo do valor de troca fundado na equivalência mercantil". ${ }^{15}$

A democracia aparece assim pelo que ela é: uma forma de dominação política historicamente determinada por seu indissociável liame com as esferas da circulação e da produção burguesas, e cujo funcionamento exclui os trabalhadores do poder real, de tal sorte que, quando lutam em defesa da democracia, e independentemente das representações que fazem de sua própria luta, os trabalhadores estarão sempre reforçando as condições de sua própria subordinação ao capital.

${ }^{12}$ Evgeni Pachukanis, Obschaia teoriia prava i marksizm, Moscou, "Nauka", 1980, p. 130.

${ }^{13}$ Como diz Marx, “O processo do valor de troca que a circulação desenvolve não só respeita a liberdade e a igualdade, mas estas são o produto desse processo, o qual é a sua base real", in Zur Kritik der politischen Ökonomie, in Mega II/2, Berlim, Dietz, 1980, p. 60.

${ }^{14} \mathrm{Na}$ expressão de Bernard Edelman. Cf. Histoire et vie privée, in La personne en danger, Paris, Puf, 1999, p. 140.

${ }^{15}$ Márcio Bilharinho Naves, Marxismo e direito - um estudo sobre Pachukanis, São Paulo, Boitempo, p. 84. 